\title{
Uwarunkowania rozwoju kapitału ludzkiego na obszarach wiejskich województwa podlaskiego
}

\author{
Conditions for Development of Human Capital in Rural Areas of the Podlaskie \\ Voivodeship
}

Streszczenie: Rozwój społeczno-gospodarczy powoduje ciągłe zmiany w strukturze i hierarchii czynników determinujących ewoluowanie gospodarek. Dotyczy to także obszarów wiejskich. W każdym regionie kraju mogą występować różnice w poziomie rozwoju gospodarczego i jakości życia jego mieszkańców. Wynika to m.in. z posiadanych zasobów ludzkich oraz ich jakości i funkcji, które pełnią w życiu społecznym. Jednym z najistotniejszych czynników rozwoju społeczno-ekonomicznego regionu jest kapitał ludzki. Jego rola i zasoby są uwarunkowane nie tylko wielkością populacji, lecz także wiedzą, przedsiębiorczością, kreatywnością, zdolnościami, zdrowiem i innymi podobnymi cechami. Rozwój czynnika ludzkiego stanowi istotny kierunek działania w rozwiązywaniu problemów społeczno-ekonomicznych na obszarach wiejskich województwa podlaskiego. W dobie rozwiniętej komputeryzacji, technologii i innowacji, aby sprostać wyzwaniom przyszłości, konieczne staje się wykorzystywanie wiedzy, kwalifikacji i umiejętności zasobów ludzkich jako najcenniejszego kapitału każdego przedsiębiorstwa XXI wieku. Celem niniejszej pracy jest przedstawienie kluczowych uwarunkowań rozwoju kapitału ludzkiego na obszarach wiejskich województwa podlaskiego.

\begin{abstract}
Socio-economic development results in constant changes in the structure and in the hierarchy of factors determining the evolution of economies. This also applies to rural areas. In every region of the country there may be differences in the level of economic development and quality of life of its inhabitants. This is due to, among other things, their human resources and their quality and their function in society. One of the most important factors of socio-economic development of the region is human capital. Its role and resources are conditioned not only by the size of the population, but mainly knowledge, entrepreneurship, creativity, ability, health, and other similar features in the region. The development of the human factor is an important course of action in solving socio-economic problems in rural areas Podlaskie. In the age of the developed computerization, the technology and the innovation in order to meet challenges of the future, it is becoming necessary to use the knowledge, qualifications and the abilities of human resources as most valuable capital of every enterprise of the 20th century. The aim of this study is to present the key determinants of human capital development in rural areas of Podlaskie.
\end{abstract}

Słowa kluczowe: kapitał ludzki; obszary wiejskie; uwarunkowania rozwoju

Keywords: conditions for development; human capital; rural areas 
Otrzymano: 27 października 2015

Received: 27 October 2015

Zaakceptowano: 14 marca 2016

Accepted: 14 March 2016

\section{Sugerowana cytacja/Suggested citation:}

Gabińska, C.G. (2016). Uwarunkowania rozwoju kapitału ludzkiego na obszarach wiejskich województwa podlaskiego. Przedsiębiorczość - Edukacja, 12, 52-67.

\section{WSTĘP}

W ciągu kilkunastu ostatnich lat nastąpiło wiele zmian w funkcjonowaniu gospodarki światowej. Do jednych z ważniejszych zjawisk można zaliczyć nasilenie się procesów globalizacyjnych i znaczenia wiedzy oraz coraz szybsze tempo starzenia się wiedzy i postępu technicznego. O szansach rozwoju w coraz większym stopniu decydują potencjał intelektualny oraz wiedza związana z najnowszymi osiągnięciami współczesnej nauki. Konieczne wydaje się zatem zrozumienie uwarunkowań stanowiących podstawę dla rozwoju nowej gospodarki. Głównym motorem rozwoju gospodarczego jest kapitał ludzki w połączeniu z nowoczesnymi technologiami. Powinny w nim dominować takie cechy, jak kreatywność i umiejętność analizowania oraz rozwiązywanie problemów. Zagadnienie kapitału ludzkiego na obszarach wiejskich należy rozpatrywać w powiązaniu ze specyfiką tego środowiska i kierunkami jego przemian. Za atrybuty obszarów wiejskich powszechnie uznaje się wyróżniki:

- przestrzenno-demograficzne, podkreślające odrębność terytorialną miejsca i zamieszkującej je zbiorowości,

- społeczne, które akcentują wymiar specyfiki funkcjonowania tamtejszej wspólnoty, odzwierciedlony m.in. w warunkach życia, relacjach interpersonalnych, instytucjach,

- ekonomiczne - gdzie akcentuje się istotność rolnictwa dla lokalnej gospodarki, specyfikę pracy w tym sektorze oraz odmienną od miejskiej organizację rynków (Kaleta, 2009).

W niniejszym artykule jako cel pracy wyznaczono identyfikację i analizę niektórych uwarunkowań rozwoju kapitału ludzkiego na obszarach wiejskich województwa podlaskiego. Skupiono się na analizie teoretycznych aspektów i istoty kapitału ludzkiego oraz wybranych jego elementów w świetle przedstawionych analiz sporządzonych na podstawie danych pochodzących z Głównego Urzędu Statystycznego (GUS), Banku Danych Lokalnych (BDL) i Urzędu Statystycznego Województwa Podlaskiego. Ponadto podjęto próbę opisania możliwości podnoszenia kwalifikacji i wiedzy na obszarach wiejskich. Przyjęto tezę, że wzrost wybranych determinantów kapitału ludzkiego poprawia jego jakość na obszarach wiejskich. Wyniki badań przedstawiono w formie opisowej i tabelarycznej.

\section{Teoretyczne aspekty i istota kapitału ludzkiego}

Kapitał ludzki jest pojęciem bardzo „obciążonym” teoretycznie i empirycznie. W literaturze spotkać można wiele nie zawsze precyzyjnie formułowanych jego wyjaśnień. Wieloznaczność w rozumieniu tego pojęcia wynika z poziomu prowadzonych rozważań, stosowania odmiennych założeń badawczych przez poszczególne osoby oraz przekładu literatury zagranicznej na język polski. 
Poziom rozwoju obszarów wiejskich zależy od wielu czynników (Heffer, Rosner, 2005; Bański, 2008), których znaczenie zmieniało się w czasie i przestrzeni. W XIX w. to ziemia oraz kapitał fizyczny i finansowy odgrywały decydującą rolę w rozwoju gospodarczym. Na przełomie XX i XXI w. do najważniejszych faktorów zalicza się kapitał ludzki i społeczny. Wielofunkcyjny rozwój obszarów wiejskich oraz wprowadzanie gospodarki opartej na wiedzy powodują wzrost zapotrzebowania na wykwalifikowaną kadrę również na wsi. Dotychczasowe badania jednoznacznie wskazują, że mieszkańcy polskiej wsi byli gorzej wykształceni niż osoby zamieszkujące miasta (Janc, Czapiewski, 2014; Frienkel, 2012).

Kapitał ludzki najczęściej analizowany jest w dwóch aspektach:

- wąskim - utożsamianym z poziomem wykształcenia osób zamieszkujących dany obszar,

- szerokim - odnoszącym się do wrodzonych zdolności, zasobu wiedzy, poziomu wykształcenia, doświadczenia zawodowego, umiejętności tworzenia i adaptowania innowacji, stanu zdrowia jednostki, jej poziomu kulturalnego oraz aktywności społeczno-ekonomicznej. Podstawy teorii kapitału ludzkiego sięgają lat 60. XX w. i wiążą się z pracami: J. Mincera (1958), G.S. Beckera (1960), T.W. Schultza (1962) oraz E.F. Denisona (1962). Do końca lat 70. $\mathrm{XX}$ w. teorie dotyczące kapitału ludzkiego łączone były z poziomem wykształcenia (szkolnictwa) i zdrowiem, co miało wpływ na wysokość uzyskiwanych przez jednostkę zarobków. Po tym okresie pojawił się nowy nurt zapoczątkowany przez R. Lukasa (1988), który twierdził, że potencjalny, przyszły poziom kapitału ludzkiego jest uzależniony od umiejętności. Lukas udowodnił, że akumulacja kapitału ludzkiego uzależniona jest od procesu uczenia się przez działanie (Cichy, 2005). Pod koniec XX w. G.S. Becker wzbogacił swoją dotychczasową teorię o nowe wątki. Stwierdził, że inwestowanie w kapitał ludzki (wiedza zawarta w ludziach) jest jednym z głównych determinant wzrostu gospodarczego. Teorie kapitału ludzkiego rozpatrywał również M. Blang, który wyjaśniał motywy jednostek związane z ponoszeniem wydatków na edukację i szkolenia. Stwierdził on, że istnieje ścisły związek między wydatkami na edukację a osiągniętym w życiu zawodowym poziomem dochodów (Łukasiewicz, 2009). Podobnie P. Romer (1990) kapitał ludzki traktował jako zasób. Według R.J. Barro i S.I. Martina (2004), kapitał ludzki wpływa na wydajność pracowników, która zależy od jakości siły roboczej i jej kwalifikacji. Można to potwierdzić badaniami przeprowadzonymi przez R.J. Barro i X. Sala-i-Martina (2004). Jednak rozmiary tych efektów są kwestionowanie przez R. Barro i J. Lee.

Według G. Łukasiewicza (2009), na kapitał ludzki składają się dwa wymiary, tj. wymiar rynkowy (zasoby wiedzy, umiejętności, zdolności, zdrowia) i osobisty (zasoby kapitału ludzkiego rozpatrywane przez pryzmat zainteresowań i hobby).

S.R. Domański (1993) w swojej publikacji kapitał ludzki definiuje w następujący sposób „[...] kapitał ludzki - można określić jako zasób wiedzy, umiejętności, zdrowia, energii witalnej zawarty w społeczeństwie. Zasób ten jest dany przez genetyczne cechy populacji raz na zawsze, ale można go powiększać inwestycjami w człowieka. Nie można oddzielić kapitału ludzkiego od człowieka" (Król, Ludwiczyński, 2006: 111).

W literaturze spotyka się wiele pojęć określających kapitał ludzki. Z punktu widzenia rozwoju przedsiębiorstwa (w tym także gospodarstwa rolnika) jako najistotniejsze należałoby wymienić następujące definicje:

- L. Edvinssona, gdzie kapitał ludzki z kapitałem strukturalnym tworzy kapitał intelektualny. Warunkiem jest zdobywanie wiedzy i jej wykorzystywanie na rzecz wykonywania pracy w firmie (gospodarstwie) (Kaplan, Norton, 2001);

- J. Fitz-Enza, która opisuje kapitał ludzki w odniesieniu do działalności gospodarczej „[...] jako kombinacje takich czynników, jak: cechy wnoszone przez człowieka (inteligencja, 
energia, ogólnie pozytywna postawa, wiarygodność, zaangażowanie), zdolność pracownika do uczenia się (chłonność umysłu, wyobraźnia, zdolności twórcze, a także zdrowy rozsądek), motywacja pracownika do dzielenia się informacjami i wiedza (duch zespołowy i orientacja na cel) (Fitz-Enz, 2001). Kapitał ludzki jest tym czynnikiem rozwojowym obszarów wiejskich, który jest niezbędny do wykorzystania innych czynników prorozwojowych. Kluczowym czynnikiem wpływającym na jego zasoby i jakość są zmiany demograficzne. (Szanse i zagrożenia..., 2013). Kapitał ludzki w skali makro to zasoby wiedzy, umiejętności, zdrowia i energii zawartych w społeczeństwie, które wywierają istotnych wpływ na innowacyjność gospodarek i społeczeństw, wpływają na ich przemiany instytucjonalne, upowszechniają określone wzorce konsumpcji i jakości życia, a także kształtują określoną strukturę techniczną, organizacyjną i społeczną gospodarki.

Na jakość kapitału ludzkiego w skali makro wpływają głównie następujące czynniki:

- zdobyty poziom wykształcenia,

- przekształcenia strukturalne gospodarki stymulujące określony popyt na pracę,

- polityka rodzinna dla kształcenia i wychowania młodego pokolenia,

- migracje ludności, gromadzenie i przepływ informacji, a także badania naukowe,

- ochrona zdrowia i środowiska naturalnego wpływająca na długość życia i sprawność fizyczną.

Wymienione czynniki oddziałują na potencjał i jakość kapitału ludzkiego stymulującego rozwój społeczno-gospodarczy regionu.

Ogromnym atutem obszarów wiejskich są ludzie, często od wielu pokoleń związani z ziemią, ciężką pracą i wartościami kulturowymi lokalnych społeczności. Jak przyjmuje Z. Zioło (2010), procesy zwiększania jakości zasobów intelektualnych dokonują się w zmieniających się uwarunkowaniach społeczno-gospodarczych, kulturowych oraz politycznych i w istotnym stopniu zależą od przemian demograficznych. W wyniku aktywizacji zawodowej część zasobów zostaje przekształcone w kapitał ludzki.

\section{Wybrane elementy kapitału ludzkiego na obszarach wiejskich w województwie podlaskim}

W poszukiwaniu uwarunkowań i rozwoju kapitału ludzkiego analizuje się przede wszystkim jego elementy składowe (determinanty). W niniejszej pracy analizie poddano odpływ zasobów kapitału ludzkiego oraz omówiono wybrane składniki, takie jak poziom wykształcenia, wiedza i kwalifikacje ludności województwa podlaskiego z wyodrębnieniem obszarów wiejskich.

Do pokazania zarówno efektów odpływu zasobów ludzkich, jak i poziomu wykształcenia autorka wykorzystała analizę danych statystycznych sporządzoną na podstawie Roczników Statystycznych GUS z lat 2003-2014 oraz Roczników Demograficznych z lat 2003-2014, Narodowych Spisów Powszechnych z lat 2002-2010, biuletynów „Ludność, ruch naturalny i migracje w województwie podlaskim" z lat 2010-2014 oraz danych pochodzących z Banku Danych Lokalnych.

Odpływ zasobów ludzkich w województwie podlaskim przejawia się w:

- spadku liczby mieszkańców w poszczególnych powiatach i podregionach,

- spadku odsetka kobiet w wieku 20-29 lat w ogólnej populacji,

- rosnącym odsetku kobiet z grupy wiekowej 20-29 na migracji wewnętrznej i zewnętrznej. 
Liczba ludności województwa podlaskiego systematycznie spada, chociaż w 2011 r. wystąpił niewielki wzrost. W latach 2003-2014 ubyło ponad 13 tys. mieszkańców (13 199). Największe spadki następują w powiatach: hajnowskim, siemiatyckim, bielskim i sokólskim. Powiaty te charakteryzuje również najniższy odsetek kobiet w wieku 20-29 lat w ogólnej populacji. Szczególne spadki odsetek kobiet w tej grupie wiekowej nastąpiły w powiatach: augustowskim z 7,90 w 2003 r. do 7,76 w 2014 r., sejneńskim z 7,72 w 2003 r. do 7,34 w 2014 r., grajewskim z 8,42 w 2003 r. do 8,15 w 2014 r. oraz zambrowskim z 7,87 w 2003 r. do 7,68 w 2014 r. (tab. 1).

Tab. 1. Udział kobiet wieku 20-29 lat w populacji (stan na 31 grudnia danego roku, dane wyrażone w \%)

\begin{tabular}{|l|c|c|c|c|c|c|c|}
\hline Wyszczególnienie & $\mathbf{2 0 0 3}$ & $\mathbf{2 0 0 5}$ & $\mathbf{2 0 0 8}$ & $\mathbf{2 0 1 1}$ & $\mathbf{2 0 1 2}$ & $\mathbf{2 0 1 3}$ & $\mathbf{2 0 1 4}$ \\
\hline Województwo & 8,42 & 8,71 & 8,88 & 8,47 & 8,33 & 8,16 & $\mathbf{8 , 0 1}$ \\
\hline Powiat augustowski & 7,90 & 8,19 & 8,63 & 8,21 & 8,08 & 7,89 & $\mathbf{7 , 7 6}$ \\
\hline Powiat białostocki & 8,09 & 8,45 & 8,67 & 8,35 & 8,22 & 7,98 & $\mathbf{7 , 8 5}$ \\
\hline Powiat bielski & 6,76 & 7,23 & 7,85 & 7,73 & 7,61 & 7,48 & $\mathbf{7 , 3 2}$ \\
\hline Powiat hajnowski & 6,42 & 6,94 & 7,37 & 7,00 & 6,78 & 6,62 & $\mathbf{6 , 4 8}$ \\
\hline Powiat moniecki & 7,59 & 7,93 & 8,50 & 8,35 & 8,23 & 8,08 & $\mathbf{7 , 8 4}$ \\
\hline Powiat sejneński & 7,72 & 7,93 & 8,15 & 7,81 & 7,67 & 7,51 & $\mathbf{7 , 3 4}$ \\
\hline Powiat siemiatycki & 6,96 & 7,32 & 7,83 & 7,58 & 7,46 & 7,31 & $\mathbf{7 , 2 2}$ \\
\hline Powiat sokólski & 7,47 & 7,94 & 8,29 & 7,83 & 7,78 & 7,62 & $\mathbf{7 , 4 9}$ \\
\hline Powiat suwalski & 7,07 & 7,42 & 8,38 & 8,33 & 8,25 & 8,18 & $\mathbf{7 , 9 9}$ \\
\hline Powiat grajewski & 8,42 & 9,03 & 9,21 & 8,53 & 8,45 & 8,28 & $\mathbf{8 , 1 5}$ \\
\hline Powiat kolneński & 7,82 & 8,26 & 8,54 & 8,44 & 8,31 & 8,13 & $\mathbf{8 , 0 4}$ \\
\hline Powiat łomżyński & 7,45 & 7,82 & 8,59 & 8,19 & 7,98 & 7,85 & $7,7 \mathbf{1}$ \\
\hline Powiat wysokomazowiecki & 7,45 & 7,98 & 8,54 & 8,05 & 7,82 & 7,68 & $\mathbf{7 , 5 1}$ \\
\hline Powiat zambrowski & 7,87 & 8,30 & 8,83 & 8,29 & 7,92 & 7,79 & $\mathbf{7 , 6 8}$ \\
\hline
\end{tabular}

Źródło: opracowanie własne na podstawie: Roczniki Statystyczne GUS z lat 2003-2014

Ważnym zagadnieniem jest też struktura wiekowa i struktura według płci emigrujących. Jeśli przeanalizujemy szczegółowo samą grupę kobiet, to około 40\% wyjeżdżających stanowią kobiety w wieku 20-29 lat. Nieco mniejszy jest odsetek kobiet w wieku 20-24 lata - choć w roku 2008 wyemigrowało prawie 12\% (11,80\%). Natomiast kobiety w wieku 25-29 lat stanowią nawet ponad $57 \%$ wyjeżdżających.

Województwo podlaskie zawsze charakteryzował odpływ ludności ze wsi do miast. Analiza okresu 2003-2014 pokazuje, że znacznie ponad 50\% wyjeżdżających z województwa podlaskiego stanowią kobiety - w 2012 r. stanowiły one ponad 55\% (55,93\%) wszystkich wyjeżdżających. Ogólnie w grupie wiekowej 20-29 lat bezwzględny odpływ kobiet jest o wiele większy niż mężczyzn. Szczególnie uwidacznia się to w grupie wiekowej 20-24 lata: wyjeżdżających kobiet jest tu ponad dwa razy więcej niż mężczyzn, np. w roku 2008 wyjechało poza granicę województwa 1470 kobiet i 460 mężczyzn, a w roku 2012 - 1058 kobiet i 408 mężczyzn. Taki obraz struktury emigrujących z województwa wynika przede wszystkim z mniejszej liczby ofert pracy dla kobiet w grupie wiekowej 20-24 lata, przy czym w tym wieku podejmowane są decyzje co do miejsca dalszego kształcenia i ewentualnej pracy. W następnej grupie zwiększa się już liczba wyjeżdżających mężczyzn, chociaż i tutaj kobiety mają bezwzględną przewagę (tab. 2). 
Tab. 2. Migracje wewnętrzne w województwie podlaskim według wieku i płci w latach 2003-2008, 2011$-2014$

\begin{tabular}{|l|r|r|r|r|r|r|r|}
\hline Wyszczególnienie & $\mathbf{2 0 0 3}$ & $\mathbf{2 0 0 5}$ & $\mathbf{2 0 0 8}$ & $\mathbf{2 0 1 1}$ & $\mathbf{2 0 1 2}$ & $\mathbf{2 0 1 3}$ & $\mathbf{2 0 1 4}$ \\
\hline Odpływ ogółem & 14874 & 14000 & 12458 & 13760 & 13054 & 13332 & 13206 \\
\hline Odpływ K & 8092 & 7736 & 7160 & 7618 & 7301 & 7384 & 7352 \\
\hline \% odpływu K & 54,40 & 55,26 & 57,47 & 55,36 & 55,93 & 55,39 & 55,67 \\
\hline Odpływ K 20-24 lata & 1529 & 1457 & 1470 & 1164 & 1058 & 1042 & 1056 \\
\hline \% odpływu K 20-24 lata & 10,28 & 10,41 & 11,80 & 8,46 & 8,10 & 7,82 & 8,00 \\
\hline \% odpływu K 20-24 & 18,90 & 18,83 & 20,53 & 15,28 & 14,49 & 14,11 & 14,36 \\
\hline Odpływ K 25-29 lat & 1659 & 1652 & 1645 & 1970 & 1957 & 1863 & 1872 \\
\hline Odpływ K 25-29 do ogółu K & 11,15 & 11,80 & 13,20 & 14,32 & 14,99 & 13,97 & 14,18 \\
\hline K 25-29 do odpływu K (\%) & 20,50 & 21,35 & 22,97 & 25,86 & 26,80 & 25,23 & 25,46 \\
\hline Odpływ M 20-24 lata & 698 & 650 & 460 & 464 & 408 & 416 & 433 \\
\hline Odpływu M 20-24 lata (\%) & 4,69 & 4,64 & 3,69 & 3,37 & 3,13 & 3,12 & 3,28 \\
\hline Odpływ M 25-29 lat & 1278 & 1248 & 996 & 1299 & 1138 & 1148 & 1187 \\
\hline Odpływ M 25-29 lat (\%) & 8,59 & 8,91 & 7,99 & 9,44 & 8,72 & 8,61 & 8,99 \\
\hline
\end{tabular}

${ }^{\star} \mathrm{K}$ - kobiety, ${ }^{\star *} \mathrm{M}$ - mężczyźni

Źródło: opracowanie własne na podstawie Roczników Statystycznych GUS z lat 2004-2014 i danych z BDL

Odpływ zasobów kapitału ludzkiego, wyludnianie się terenów wschodniej Polski ma też swoje przyczyny historyczne. Można tu wspomnieć o emigracji po powstaniach narodowych, ale także o represjach i wywózkach na Syberię w czasie i po drugiej wojnie światowej. Współcześnie przyczynia się do tego globalizacja, jak też prowadzona polityka regionalna. Przeszkody w pokonywaniu bariery odpływu zasobów ludzkich tkwią także w przyjmowaniu przez lokalne samorządy stereotypowych rozwiązań administracji rządowych i powielaniu w lokalnych strategiach rozwoju wytycznych Ministerstwa Rozwoju Regionalnego. Strategia rozwoju województwa podlaskiego do roku 2020 (Strategia..., 2013) ujmuje wprawdzie problemy demograficzne regionu, ale dopiero w trzecim Celu Strategicznym - cel operacyjny 3.1. Jakość życia. „Problemy demograficzne, takie jak spadek liczby ludności, starzenie się społeczeństwa, presja migracyjna, dysproporcje w rozmieszczeniu siły roboczej, wskazywane są jako kluczowe wyzwania polityki społeczno-gospodarczej nie tylko na poziomie europejskim, krajowym, ale także regionalnym. W odniesieniu do województwa podlaskiego, niewątpliwie jednym z głównych problemów jest ujemne saldo migracji oraz prognozowany dalszy spadek liczby ludności. W świetle powyższych zagrożeń nieuniknione jest podjęcie działań mających na celu neutralizowanie efektów zmian demograficznych, w tym podtrzymanie aktywności zawodowej i społecznej. Należy poprawić dostępność oraz jakość edukacji przedszkolnej.

Kapitał ludzki jako efekt edukacji nie pozostaje bez wpływu na jakość życia człowieka, jego miejsce w strukturze społecznej...” (Przyszczykowski, 2002: 133)

Wychowanie przedszkolne jako pierwszy etap edukacji prowadzone jest w przedszkolach i oddziałach przedszkolnych przy szkołach podstawowych oraz od roku szkolnego 2008/2009 zgodnie z Rozporzadzeniem Ministra Edukacji Narodowej z 31.08.10 r. (Dz.U. nr 161, poz. 1080) również w zespołach wychowania przedszkolnego i punktach przedszkolnych. Jednak z danych GUS-u i BDL wynika, że ciągle ten odsetek nie jest zadawalający. W miastach sytuacja jest zdecydowanie lepsza niż na obszarach wiejskich (tab. 3). 
Tab. 3. Wychowanie przedszkolne w województwie podlaskim w latach 2008-2015

\begin{tabular}{|l|r|r|r|r|r|r|r|}
\hline Wyszczególnienie & $\mathbf{2 0 0 8 / 0 9}$ & $\mathbf{2 0 1 0 / 1 1}$ & $\mathbf{2 0 1 1 / 1 2}$ & $\mathbf{2 0 1 2 / 1 3}$ & $\mathbf{2 0 1 3 / 1 4}$ & $\mathbf{2 0 1 4 / 1 5}$ & $\begin{array}{c}\mathbf{2 0 0 8 / 0 9 =} \\
=\mathbf{1 0 0}\end{array}$ \\
\hline Placówki & 544 & 609 & 644 & 676 & 689 & 680 & 125,0 \\
\hline w tym na wsi & 335 & 370 & 396 & 403 & 398 & 385 & 114,9 \\
\hline Miejsca w placówkach & 18785 & 22358 & 23798 & 25443 & 26402 & 26929 & 143,4 \\
\hline w tym na wsi & 1440 & 2873 & 3626 & 4129 & 4073 & 4104 & 285,5 \\
\hline Oddziały & 1220 & 1417 & 1564 & 1630 & 1720 & 1696 & 139,5 \\
\hline w tym na wsi & 363 & 441 & 506 & 534 & 543 & 514 & 141,5 \\
\hline Dzieci & 26106 & 30073 & 33527 & 34972 & 36314 & 34099 & 130,6 \\
\hline w tym na wsi & 5521 & 6814 & 8504 & 8854 & 9283 & 8477 & 153,5 \\
\hline w tym w wieku 6 lat & 10315 & 9271 & 8718 & 8947 & 9246 & 6181 & 59,9 \\
\hline w tym na wsi & 3635 & 2952 & 2719 & 2693 & 2730 & 1699 & 46,7 \\
\hline
\end{tabular}

Źródło: opracowanie własne na podstawie danych z BDL i GUS-u z lat 2009-2015

Jak wynika z tabeli, w województwie podlaskim od roku szkolnego 2008/2009 do roku szkolnego 2014/2015 nastąpił wzrost zarówno liczby placówek przedszkolnych (o 25\%), również tych usytuowanych na wsi (o 14,9\%), jak też liczby miejsc w przedszkolach $(43,4 \%)$, w tym na wsi (18,5\%). Wzrosła też liczba dzieci w przedszkolach ogółem (o 30,6\%), ale na wsi uwidocznił się spadek o 53,3\%. Natomiast po przeanalizowaniu ostatnich dwóch lat nauki, tj. roku 2013/2014 i 2014/2015 widać, oprócz wzrostu liczby miejsc w przedszkolach (o 1\%), w tym na wsi (o 1,01\%), że liczba placówek zmniejszyła się o 9 (1,3\%). Wychowaniem przedszkolnym zapewniającym opiekę i naukę objęto 34,1 tys. dzieci (spadek o 6,1\% w stosunku do poprzedniego roku). Większość omawianych placówek zlokalizowanych było na wsi (56,6\%), jednak tylko 24,9\% ogółu dzieci objętych edukacją przedszkolną stanowiły dzieci wiejskie. W roku szkolnym 2014/2015 na jedną placówkę wychowania przedszkolnego przypadło średnio 50 dzieci (w tym na wsi 22). Obsada miejsc w podlaskich przedszkolach kształtowała się na poziomie 96 dzieci na 100 miejsc.

Biorąc pod uwagę szkoły podstawowe zlokalizowane w województwie podlaskim, należy zauważyć, że na terenach wiejskich w latach 2013/2014 i 2014/2015 było ich o 73,4\% więcej niż w miastach (tab. 4), gdzie do szkół podstawowych uczęszcza o 46247 mniej uczniów (31,6\%).

Tab. 4. Szkoła podstawowa i gimnazja dla dzieci i młodzieży w województwie podlaskim w latach 2008-2015

\begin{tabular}{|l|r|r|r|r|r|r|r|}
\hline Wyszczególnienie & $\mathbf{2 0 0 8 / 0 9}$ & $\mathbf{2 0 1 0 / 1 1}$ & $\mathbf{2 0 1 1 / 1 2}$ & $\mathbf{2 0 1 2 / 1 3}$ & $\mathbf{2 0 1 3 / 1 4}$ & $\mathbf{2 0 1 4 / 1 5}$ & $\begin{array}{c}\mathbf{2 0 0 8 / 0 9 =} \\
=\mathbf{1 0 0}\end{array}$ \\
\hline Szkoły podstawowe & 459 & 449 & 438 & 425 & 414 & 414 & 90,2 \\
\hline w tym wiejskie & 315 & 313 & 311 & 308 & 304 & 304 & 96,5 \\
\hline Uczniowie & 72576 & 67355 & 65986 & 64542 & 63868 & 67612 & 93,2 \\
\hline w tym na wsi & 25930 & 22961 & 22356 & 22081 & 21545 & 21365 & 82,4 \\
\hline Gimnazja & 219 & 222 & 221 & 226 & 229 & 230 & 105,0 \\
\hline w tym wiejskie & 96 & 94 & 92 & 91 & 92 & 92 & 95,8 \\
\hline Uczniowie & 45929 & 41056 & 38983 & 36750 & 34973 & 33673 & 73,3 \\
\hline w tym na wsi & 12872 & 11647 & 10897 & 10283 & 10169 & 10038 & 78,0 \\
\hline
\end{tabular}

Źródło: opracowanie własne na podstawie danych z BDL i GUS-u z lat 2009-2015 
W roku szkolnym 2014/2015 na jedną szkołę podstawową przypadało 163 uczniów, zaś rok wcześniej wskaźnik ten kształtował się na poziomie 154 osób. Na wsi na jedną szkołę przypadało 81 uczniów, podczas gdy w miastach średnio 362 uczniów. Natomiast w omawianym okresie na jedno gimnazjum dla dzieci i młodzieży przypadało średnio 146 uczniów, tj. o 7 mniej niż przed rokiem. Na wsi w jednej szkole gimnazjalnej naukę pobierało 150 uczniów, a w miastach - przeciętnie 174 uczniów.

Niezależnie od rodzaju niezbędnych umiejętności podstawą wykształcenia jest edukacja szkolna. Równomierny rozwój kapitału ludzkiego, by zaowocować w życiu dorosłym jednostki, powinien być wspierany od najniższych szczebli edukacji. Należy stwierdzić, że szkoły funkcjonujące na obszarach wiejskich województwa podlaskiego (w tym rolnicze: 16), a głównie szkoły podstawowe i gimnazja, spełniały poza sferą edukacyjną wiele ważnych funkcji w rozwoju wsi. Jedną z nich jest kreowanie kapitału ludzkiego przez oddziaływanie na postawy i aktywność mieszkańców, wzbogacenie w wiedzę i integrowanie społeczności lokalnej. Niejednokrotnie szkoły stanowiły punkt centralny wydarzeń kulturalnych czy sportowych oraz miejsca spotkań mieszkańców.

Przyjęcie szkół przez jednostki samorządu terytorialnego zwiększa możliwości poprawy jakości kapitału ludzkiego. Jedną z takich możliwości jest prowadzenie szkoleń dla dorosłych mieszkańców (kursy rolnicze, gotowania i szycia, podstawy obsługi komputera) czy wprowadzenie dodatkowych programów nauczania w szkołach, np. przedsiębiorczości. Próby takich działań można zaobserwować w niektórych szkołach województwa podlaskiego na obszarach wiejskich (szkoły podstawowe w Suchowoli, Janowie, Korycinie, Piątnicy, Lipsku itd.). Niski poziom edukacji początkowej często wskazywany jest jako jedna $\mathrm{z}$ barier ograniczających rozwój przedsiębiorczości na obszarach wiejskich. Dlatego szczególnie istotna jest rola szkół wiejskich jako potencjalnych inkubatorów przedsiębiorczości.

O rozmiarach kapitału ludzkiego w istotnym stopniu decydują czynniki demograficzne. Na podstawie przeprowadzonych rozważań należy stwierdzić, że województwo podlaskie wyludnia się i starzeje - należy do regionów, w których od co najmniej kilkunastu lat mamy do czynienia $\mathrm{z}$ trendem spadkowym w liczbie ludności. W latach 2000-2013 liczba ludności województwa podlaskiego zmniejszyła się do 1194965 osób, czyli o 26163 osoby (2,1\%; tab. 5). W tym okresie w Polsce liczba mieszkańców zwiększyła się średnio o 0,6\% z 38254 do 38502 osób (Rocznik Demograficzny 2014). Na zmniejszenie się liczby ludności ma wpływ ruch naturalny mieszkańców (urodzenia, zgony) oraz ruch wędrówkowy (migracje wewnętrzne i zagraniczne).

Tab. 5. Zmiana liczby ludności w województwie podlaskim w latach 2000-2013 według miejsca zamieszkania

\begin{tabular}{|c|c|c|c|c|c|}
\hline \multirow{2}{*}{ Rok } & \multicolumn{3}{|c|}{ Liczba ludności } & \multicolumn{2}{c|}{$\begin{array}{c}\text { Udział w ogólnej liczbie } \\
\text { ludności (w \%) }\end{array}$} \\
\cline { 2 - 6 } & ogółem & miasto & wieś & miasto & wieś \\
\hline 2000 & 1221128 & 713942 & 507186 & 58,5 & 41,5 \\
\hline 2005 & 1201000 & 710542 & 490458 & 59,2 & 40,8 \\
\hline 2010 & 1200982 & 724027 & 476955 & 60,3 & 39,7 \\
\hline 2013 & 1194965 & 721824 & 473141 & 60,4 & 39,6 \\
\hline
\end{tabular}

Źródło: opracowanie własne na podstawie danych z BDL, Roczników Statystycznych Województwa Podlaskiego z lat 2000,2010 i 2014 
Liczba ludności w województwie podlaskim wynosiła w 2014 roku 1191,9 tys. osób, z czego 51,2\% stanowiły kobiety. W latach 2003-2014 liczba ludności w województwie zmniejszyła się o ponad 13 tys. osób, a ubytek ten dotyczył głównie ludności zamieszkałej na terenach wiejskich. O ile ludność miast w regionie zwiększyła się o 9,5 tys. osób, o tyle w tym samym okresie skala wyludniania się obszarów wiejskich objęła populację 22,4 tys. osób. Saldo migracji wewnętrznych i zagranicznych na pobyt stały w latach 2003-2014 było ujemne.

Nadal pogłębiają się niekorzystne zmiany w strukturze demograficznej ludności i można postawić tezę, że nabierają one przyspieszenia. Ujemne saldo migracji może świadczyć o tym, że coraz mniej osób wiąże swoją przyszłość z zamieszkaniem i pracą w regionie podlaskim. Należy zauważyć, że w podregionie białostockim, głównie w powiecie białostockim, większość wskaźników demograficznych osiąga obecnie wartości bardziej pozytywne niż przeciętne dla województwa. W przyszłości zagrożeniem może być niski udział ludności w wieku przedprodukcyjnym w podregionie suwalskim i na obszarach wiejskich, ale może on być łatwo zniwelowany przez napływ ludności w wieku produkcyjnym z innych regionów województwa (tab. 6). Ponadto wzrasta liczba osób w wieku niemobilnym, tj. powyżej 44 roku życia, co oznacza starzenie się populacji. W $2014 \mathrm{r}$. 19\% stanowily osoby w wieku poprodukcyjnym, w tym: $42,6 \%$ na wsi i $57,4 \%$ w miastach. Wynika z tego, że w miastach województwa podlaskiego społeczeństwo starzeje się.

Tab. 6. Ludność (w tys.) według podregionów, ekonomicznych grup wieku w województwie podlaskim w $2014 \mathrm{r}$.

\begin{tabular}{|l|c|c|c|c|c|c|c|c|c|}
\hline \multirow{2}{*}{$\begin{array}{l}\text { Województwo/ } \\
\text { Podregiony }\end{array}$} & \multicolumn{2}{|c|}{ Wiek przedprodukcyjny } & \multicolumn{3}{c|}{ Wiek produkcyjny } & \multicolumn{3}{c|}{ Wiek poprodukcyjny } \\
\cline { 2 - 11 } & ogółem & miasto & wieś & ogółem & miasto & wieś & ogółem & miasto & wieś \\
\hline Woj.podlaskie & $\mathbf{2 1 0 , 5}$ & $\mathbf{1 2 3 , 9}$ & $\mathbf{8 6 , 6}$ & $\mathbf{7 5 5 , 6}$ & $\mathbf{4 6 7 , 4}$ & $\mathbf{2 8 8 , 2}$ & $\mathbf{2 2 5 , 9}$ & $\mathbf{1 2 9 , 7}$ & $\mathbf{9 6 , 2}$ \\
\hline $\begin{array}{l}\text { Podregion } \\
\text { białostocki }\end{array}$ & $\mathbf{8 8 , 1}$ & $\mathbf{6 4 , 2}$ & 23,9 & 326,7 & 245,0 & 81,6 & 96,0 & 70,8 & 25,3 \\
\hline $\begin{array}{l}\text { Podregion } \\
\text { łomżyński }\end{array}$ & 71,5 & 32,6 & 38,9 & 253,0 & 124,5 & 128,5 & 80,9 & 33,7 & 47,2 \\
\hline $\begin{array}{l}\text { Podregion } \\
\text { suwalski }\end{array}$ & 50,9 & 27,1 & 23,8 & 175,9 & 97,9 & 78,1 & 49,0 & 25,2 & 23,7 \\
\hline
\end{tabular}

Źródło: opracowanie własne na podstawie danych z BDL, Rocznika Statystycznego Województwa Podlaskiego 2014 rok

Po przeanalizowaniu struktury ludności (\%) według ekonomicznych grup wieku w województwie podlaskim w latach 2002-2014 widać niepokojący stopniowy ubytek w populacji w wieku przedprodukcyjnym, co może świadczyć o przyszłości wieku produkcyjnego, a w konsekwencji o odpływie kapitału ludzkiego. Z kolei w przypadku ludności w wieku poprodukcyjnym notuje się dokładnie odwrotną tendencję w stosunku do ludności w wieku przedprodukcyjnym. Mianowicie liczba osób w wieku poprodukcyjnym systematycznie wzrasta. Wzrost ten spowodowany jest wydłużaniem się trwania życia oraz starzenia się społeczeństwa.

Obniżenie wskaźników aktywności zawodowej, w warunkach spadku zarówno wskaźników zatrudnienia, jak i stopy bezrobocia, zaowocowało przesunięciem zasobów pracy do populacji osób biernych zawodowo. Jak wynika $\mathrm{z}$ danych zawartych w tabeli 7, utrzymuje się trend wzrostowy wskaźnika aktywności zawodowej i wskaźnika zatrudnienia przy spadku stopy bezrobocia do 2013. Jednak na obszarach wiejskich notuje się wzrost stopy bezrobocia zarejestrowanego i ukrytego (34,2\% ogółu bezrobotnych zamieszkujących obszary wiejskie województwa). 
W tak ukształtowanej sytuacji demograficznej województwa podlaskiego - charakteryzującej się spadkiem zasobów pracy, przy wzroście liczby osób w wieku poprodukcyjnym ważną kwestią staje się maksymalizacja aktywności zawodowej, prowadząca do zwiększenia stopnia wykorzystania istniejącego potencjału pracy.

Tab. 7. Wskaźniki aktywności ekonomicznej ludności powyżej 15 roku życia według płci w województwie podlaskim w latach 2003-2014 (w \%)

\begin{tabular}{|c|c|c|c|c|c|c|c|c|c|}
\hline \multirow{2}{*}{ Rok } & \multicolumn{3}{|c|}{$\begin{array}{c}\text { Wskániki aktywności } \\
\text { zawodowej }\end{array}$} & \multicolumn{2}{c|}{ Wskaźniki zatrudnienia } & \multicolumn{3}{c|}{ Stopa bezrobocia } \\
\cline { 2 - 11 } & $\mathbf{O}^{*}$ & $\mathbf{M}^{* *}$ & $\mathbf{K}^{* * *}$ & $\mathbf{O}$ & $\mathbf{M}$ & $\mathbf{K}$ & $\mathbf{O}$ & \multicolumn{1}{|c|}{ M } & \multicolumn{1}{|c|}{ K } \\
\hline 2003 & 55,4 & 64,1 & 47,5 & 45,7 & 53,1 & 38,8 & 17,7 & 17,6 & 17,8 \\
\hline 2005 & 55,1 & 62,7 & 48,2 & 46,6 & 55,1 & 38,9 & 15,6 & 12,5 & 19,4 \\
\hline 2010 & 54,6 & 61,9 & 48,0 & 49,6 & 56,5 & 43,5 & 9,0 & 8,8 & 9,3 \\
\hline 2013 & 56,0 & 62,9 & 49,7 & 50,8 & 56,9 & 45,4 & 9,3 & 9,6 & 9,0 \\
\hline 2014 & 55,8 & 64,4 & 47,8 & 50,0 & 57,7 & 42,8 & 10,5 & 10,1 & 10,5 \\
\hline
\end{tabular}

* $\mathrm{O}$ - ogółem. ${ }^{* *} \mathrm{M}$ - mężczyźni. ${ }^{* *} \mathrm{~K}$ - kobiety

Źródło: opracowanie własne na podstawie danych z BDL i GUS

Wykształcenie jest istotnym elementem sprzyjającym umocnieniu kapitału ludzkiego na obszarach wiejskich i jest ważnym wyróżnikiem potencjalnych umiejętności ludzi. Powinno mieć ono charakter permanentny i to nie tylko w mieście, ale także, a może - przede wszystkim - na obszarach wiejskich, i obejmować również rolników.

Następnym analizowanym zagadnieniem jest jakość i poziom wykształcenia, który jest czynnikiem decydującym o szansach na rynku pracy. W latach 2002-2011 w województwie podlaskim zanotowano pozytywną tendencje ogólną, wyrażającą się we wzroście poziomu wykształcenia poszczególnych regionach (tab. 8). Korzystne tendencje nie zmieniają jednak ciągle dużych dysproporcji w zakresie poziomu wykształcenia między wsią a miastem. Po $2002 \mathrm{r}$. poprawiła się też struktura wykształcenia mieszkańców miast, co jest szczególnie widoczne na poziomie wykształcenia wyższego - zanotowano wzrost z 13,2 \% w 2002 r. do 21,4 \% w 2011 r.

Tab. 8. Ludność według poziomu wykształcenia (\%) i płci w latach 2002 i 2011

\begin{tabular}{|l|r|r|r|r|r|r|r|r|r|}
\hline \multirow{2}{*}{ Wykształcenie } & \multicolumn{3}{|c|}{$\mathbf{2 0 0 2}$} & \multicolumn{3}{c|}{$\mathbf{2 0 1 1}$} & \multicolumn{3}{c|}{ Dynamika 2011/2002 } \\
\cline { 2 - 11 } & ogółem & miasto & wieś & ogółem & miasto & wieś & ogółem & miasto & wieś \\
\hline wyższe & 9,9 & 13,2 & 4,2 & 17,0 & 21,4 & 9,9 & 171,7 & 162,1 & 235,7 \\
\hline $\mathrm{M}^{\star}$ & 9,3 & 13,0 & 3,4 & 14,8 & 19,5 & 7,7 & 159,1 & 150,0 & 226,5 \\
\hline $\mathrm{K}^{\star \star}$ & 10,4 & 13,5 & 4,9 & 19,0 & 23,2 & 12,1 & 182,7 & 171,9 & 246,9 \\
\hline policealne & 3,2 & 3,9 & 1,9 & 2,6 & 3,2 & 1,6 & 81,3 & 82,1 & 84,2 \\
\hline $\mathrm{M}$ & 1,6 & 2,0 & 0,9 & 1,5 & 1,9 & 0,9 & 93,8 & 95,0 & 100,0 \\
\hline $\mathrm{K}$ & 4,6 & 5,5 & 2,9 & 3,6 & 4,4 & 2,3 & 78,3 & 80,0 & 79,3 \\
\hline średnie & 28,3 & 33,4 & 19,6 & 29,0 & 32,1 & 23,9 & 102,5 & 96,1 & 121,9 \\
\hline $\mathrm{M}$ & 26,0 & 31,4 & 17,2 & 27,6 & 31,2 & 22,2 & 106,2 & 99,4 & 129,1 \\
\hline $\mathrm{K}$ & 30,5 & 35,2 & 21,9 & 30,2 & 32,9 & 25,6 & 99,0 & 93,5 & 116,9 \\
\hline $\begin{array}{l}\text { średnie } \\
\text { zawodowe }\end{array}$ & 19,7 & 22,3 & 15,3 & 17,2 & 18,5 & 15,1 & 87,3 & 83,0 & 98,7 \\
\hline $\mathrm{M}$ & 20,6 & 24,7 & 14,9 & 18,7 & 20,6 & 15,8 & 90,8 & 85,1 & 106,0 \\
\hline
\end{tabular}




\begin{tabular}{|l|r|r|r|r|r|r|r|r|r|}
\hline $\mathrm{K}$ & 18,8 & 20,5 & 15,7 & 15,9 & 16,7 & 14,4 & 84,6 & 81,5 & 91,7 \\
\hline ogólnokształcące & 8,6 & 11,2 & 4,3 & 11,8 & 13,6 & 8,9 & 137,2 & 121,4 & 207,0 \\
\hline $\mathrm{M}$ & 5,4 & 7,3 & 2,4 & 9,0 & 10,7 & 6,4 & 166,7 & 146,6 & 266,7 \\
\hline $\mathrm{K}$ & 11,6 & 14,7 & 6,2 & 14,3 & 16,2 & 11,2 & 123,3 & 110,2 & 180,6 \\
\hline $\begin{array}{l}\text { zasadnicze } \\
\text { zawodowe }\end{array}$ & 23,2 & 20,4 & 28,0 & 21,7 & 18,6 & 26,5 & 93,5 & 91,2 & 94,6 \\
\hline $\mathrm{M}$ & 30,1 & 26,7 & 35,5 & 27,9 & 24,2 & 33,6 & 92,7 & 90,6 & 94,6 \\
\hline $\mathrm{K}$ & 16,9 & 14,9 & 20,7 & 15,9 & 13,7 & 19,6 & 94,1 & 91,9 & 94,7 \\
\hline gimnazjalne & $\mathrm{x}$ & $\mathrm{x}$ & $\mathrm{x}$ & 4,9 & 4,3 & 6,0 & $\mathrm{x}$ & $\mathrm{x}$ & $\mathrm{x}$ \\
\hline $\mathrm{M}$ & $\mathrm{x}$ & $\mathrm{x}$ & $\mathrm{x}$ & 5,5 & 4,8 & 6,5 & $\mathrm{x}$ & $\mathrm{x}$ & $\mathrm{x}$ \\
\hline $\mathrm{K}$ & $\mathrm{x}$ & $\mathrm{x}$ & $\mathrm{x}$ & 4,4 & 3,7 & 5,5 & $\mathrm{x}$ & $\mathrm{x}$ & $\mathrm{x}$ \\
\hline $\begin{array}{l}\text { podstawowe } \\
\text { ukończone }\end{array}$ & 29,8 & 23,9 & 39,7 & 18,3 & 13,7 & 25,6 & 61,4 & 57,3 & 64,5 \\
\hline $\mathrm{M}$ & 28,0 & 22,0 & 37,6 & 16,5 & 11,8 & 23,5 & 58,9 & 53,6 & 62,5 \\
\hline $\mathrm{K}$ & 31,4 & 25,6 & 41,7 & 20,0 & 15,4 & 27,8 & 63,7 & 60,2 & 66,7 \\
\hline $\begin{array}{l}\text { podstawowe } \\
\text { niedokończone } \\
\text { i bez } \\
\text { wykształcenia }\end{array}$ & 5,6 & 5,1 & 6,6 & 6,5 & 6,6 & 6,4 & 116,1 & 129,4 & 97,0 \\
\hline $\mathrm{M}$ & 5,1 & 4,9 & 5,3 & 6,2 & 6,6 & 5,7 & 121,6 & 134,7 & 107,5 \\
\hline $\mathrm{K}$ & 6,3 & 5,3 & 7,9 & 6,8 & 6,7 & 7,1 & 107,9 & 126,4 & 89,9 \\
\hline
\end{tabular}

${ }^{\star} \mathrm{M}-$ mężczyźni. ${ }^{\star} \mathrm{K}$ - kobiety

Źródło: opracowanie własne na podstawie danych z BDL, Województwo podlaskie. Podregiony, powiaty, gminy (2003; 2013)

Przejawy zmian, które nastąpiły pod względem poziomu wykształcenia na obszarach wiejskich województwa podlaskiego, to:

- istotne zwiększenie udziału mieszkańców z wyższym wykształceniem. Wśród mieszkańców wsi w 2011 r. było 9,9\% osób z wyższym wykształceniem. W stosunku do roku 2002 (przystąpienie Polski do UE) oznacza to niemal 2,5-krotny wzrost. Charakterystyczne, że wzrost dominuje wśród kobiet: w 2002 r. - 4,9\%, a w 2011 - 12,1\%;

- zmniejszenie udziału osób z wykształceniem policealnym. W 2012 było 1,9\% osób z wykształceniem policealnym, natomiast w 2011 roku - 1,6\% wśród mieszkańców wsi. Populacją dominującą byli mężczyźni, ale na jednakowym poziomie $0,9 \%$, chociaż po całościowej analizie dotyczącej wykształcenia policealnego widać, że dla kobiet to 2,3\%, a dla mężczyzn - 0,9\%;

- zwiększenie udziału osób z wykształceniem średnim. Wśród mieszkańców obszarów wiejskich w 2002 r. było ich 19,6 \%, a w 2011 - 23,9\%. Wzrost zanotowano w obu populacjach;

- znikome zmniejszenie udziału mieszkańców z wykształceniem średnim zawodowym (odpowiednio 15,3\% i 15,1\%). Wzrost osiąga większe wskaźniki wśród mężczyzn - w 2002 r. - 14,9\%, a w 2011 r. - 15,8\%;

- ponad dwukrotne zwiększenie udziału osób z wykształceniem średnim ogólnokształcącym. Wśród mieszkańców wsi było ich w 2002 r. 4,3\%, a w 2011 r. - 8,9\%. Oczywiście dominują kobiety (odpowiednio 6,2\% i 11,2\%); 
- zmniejszenie udziału osób z wykształceniem podstawowym (ukończonym). W latach 2002-2011 nastąpił spadek z 39,7\% w 2002 r. do 25,6\% w 2011 r. Spadek nastąpił wśród mężczyzn (odpowiednio 37,6\% i 23,5\%) i kobiet (odpowiednio 41,7\% i 27,8\%);

- podobnie jak wyżej zmniejszenie udziału osób z wykształceniem podstawowym nieukończonym, bez wykształcenia bądź wykształceniem nieustalonym. W latach 2002-2011 nastąpił spadek z 6,6\% w 2002 r. do 6,4\% w 2011 r. W populacji mężczyzn nastąpił wzrost z 5,3\% w 2002 r. do 5,7\% w 2011 r., natomiast w populacji kobiet nastąpił spadek z 7,9\% w 2002 r. do 7,1\% w 2011 r. Należy jednak zauważyć, że w porównaniu z 2002 r. bardzo wyraźnie zmniejszyły się dysproporcje.

$\mathrm{Na}$ obszarach wiejskich i w miastach województwa podlaskiego widać podobne kierunki zmian. Tylko udział osób z wykształceniem zasadniczym zawodowym i podstawowym zmalał w mieście i na wsi. Zwiększenie udziału osób lepiej wykształconych na obszarach wiejskich wynika z coraz większych aspiracji i możliwości edukacyjnych młodego pokolenia, natomiast kształcenie i doskonalenie dorosłych na Podlasiu, a szczególnie na obszarach wiejskich - ma bardzo ograniczony zasięg.

Zmniejszenie różnic w poziomie wykształcenia między wsią a miastem jest problemem, na który składa się wiele czynników. Jednym z nich jest rozproszenie szkół na obszarach wiejskich, co wymusza konieczność dowożenia dzieci z dalej położonych miejscowości. Następny istotny czynnik to jakość kształcenia, która jest sumą stanu kadry nauczycielskiej i jej kwalifikacji oraz wyposażenia szkół w sprzęt komputerowy oraz specjalistyczne pracownie. Natomiast w przypadku dostępności młodzieży z obszarów wiejskich do szkół wyższych decydującą rolę odgrywają możliwości finansowe podjęcia nauki z dala od miejsca zamieszkania oraz poniesienia kosztów tej nauki. Niemniej istotne są też aspiracje młodych ludzi i chęć podjęcia nauki.

\section{Wiedza i możliwości podnoszenia kwalifikacji na obszarach wiejskich}

Wiedza jako kreator postępu na obszarach wiejskich stała się głównym czynnikiem rzutującym na tempo postępu ekonomicznego i społecznego. Zdobywanie nowej wiedzy i poprawa poziomu wykształcenia ludności są zatem warunkami koniecznymi do spełnienia w realiach globalnej gospodarki. Rolnikom czy też mieszkańcom obszarów wiejskich brak jest często świadomości korzyści wynikających z posiadania wiedzy ogólnej i zawodowej, świadomości tego, że dzięki wiedzy będzie im łatwiej poruszać się w środowisku przyrodniczym i społecznym. Dzisiaj każdy z nas musi identyfikować luki w swej wiedzy, kwalifikacjach, i szukać sposobów ich uzupełnienia. Koniecznością staje się ciągłe wydłużanie okresu edukacji. Tak więc samodzielność, kreatywność, komunikatywność, interdyscyplinarność to cechy, jakimi powinien charakteryzować się kapitał ludzki.

W kontekście obszarów wiejskich rosnące znaczenie w życiu społeczno-gospodarczym zasobów niematerialnych, takich jak kwalifikacje czy umiejętności, postrzega się zazwyczaj jako nowe szanse rozwojowe. Inną możliwością podnoszenia kwalifikacji przez osoby dorosłe na obszarach wiejskich, które spełniły obowiązek szkolny, są pozaszkolne formy kształcenia, ukierunkowane na uzyskiwanie i uzupełnianie wiedzy oraz umiejętności zawodowych. Podstawowymi formami kształcenia, dokształcania i doskonalenia w formach pozaszkolnych w latach 2014/2015 były: szkolenia, kursy, kursy zawodowe i seminaria. 
W analizowanym województwie ważna rola została wyznaczona instytucjom, które przez działania informacyjne i doradcze mogą w znacznym stopniu stymulować rozwój. Podlaski Ośrodek Doradztwa Rolniczego w Szepietowie i Wojewódzki Urząd Pracy w Białymstoku wspierają rozwój gospodarstw przez szkolenia („Podatek VAT w rolnictwie”), kursy zawodowe („Podejmowanie własnej działalności gospodarczej”), seminaria („Integrowana ochrona roślin”), wyjazdy studyjne, prelekcje, promocje przedsiębiorczości. Szkolenia WUP w Białymstoku w latach 2014-2015 w ramach programu operacyjnego „Wiedza - edukacja - rozwój” to: grafika komputerowa, pracownik magazynu, spawanie metodą MAG i TIG, kierowca wózków jezdniowych, przewóz materiałów niebezpiecznych, Auto CAD i Solid Works z kosztorysowaniem, operator koparko-ładowarki itp. Oferta szkoleniowa była dostosowana do realnych potrzeb odbiorców, tak aby w kształceniu mieszkańców wsi brać pod uwagę nowe rodzaje wiedzy i podnoszenie świadomości potencjału gospodarczego terenów wiejskich.

O sile kapitału ludzkiego decyduje nie tylko kapitał człowieka, oparty na posiadanej wiedzy i doświadczeniu, ale także możliwości jego dalszego rozwoju (Czaja, 2011). System edukacji jest lustrzanym odbiciem wartości dominujących w regionie i całym społeczeństwie. Kształcenie ustawiczne, edukacja przez całe życie są kluczowe dla XXI w. Dziś nie można mówić, że człowiek zgromadzi w swojej młodości podstawowy zasób wiedzy, który wystarczy mu na całe życie. Edukacja powinna obejmować czas od dzieciństwa po kres życia.

W rozwoju konkurencyjnej gospodarki opartej na wiedzy i przedsiębiorczości edukacja osób pracujących na obszarach wiejskich Podlasia ma istotne znaczenie. Jedną z barier rozwoju regionu jest niski poziom wykształcenia, posiadanych kwalifikacji, umiejętności i wiedzy. Kształcenie się ludności wiejskiej jest koniecznością. Ludność rolnicza, wchodząc na rynek pracy lub rozwijając działalność gospodarczą w swoim regionie, musi zdawać sobie sprawę, że kwalifikacje i wykształcenie w coraz większym stopniu są towarem i że jakość siły roboczej zależy od wykształcenia. Ludzie poszerzają swoje horyzonty myślowe, lepiej rozumieją rygory gospodarki rynkowej. Są bardziej skłonni ponosić ryzyko zmian, lepiej potrafią wykorzystać pojawiające się możliwości rozwoju. Poziom kształcenia dzieci i młodzieży oraz sposoby podnoszenia kwalifikacji dorosłych mogą decydować o przyszłym charakterze obszarów wiejskich. W celu likwidacji luki edukacyjnej nie wystarczą reformy, polegające na wprowadzaniu w gimnazjum czy liceum nauki o przedsiębiorczości, ale potrzebny jest szeroki program kształcenia ludności wiejskiej, w tym też kształcenia ustawicznego. Nieustanne doskonalenie posiadanych kwalifikacji ogólnych i zawodowych wpływa na zwiększenie efektywności transferu wiedzy do praktyki i przyczynia się do postępu rolniczego.

Dzięki kształceniu ustawicznemu ludzie zdobywają dwie-trzy specjalności, są bardziej elastyczni kwalifikacyjnie, wzrasta ich mobilność zawodowa, łatwość przekwalifikowania się i w ten sposób mają zdecydowanie większe szanse na aktywne utrzymanie się na rynku pracy. Koncepcja kształcenia ustawicznego zyskuje przedsiębiorczy wydźwięk, będąc jedną z determinant jego rozwoju, które w centrum zainteresowania stawia człowieka, jego działalność rozwojową i kreatywność. Ważnym instrumentem w zakresie prowadzonego doradztwa zawodowego jest też upowszechnianie kształcenia na odległość.

Aby szkolenia w rolnictwie odzwierciedlały ekonomiczną i socjalną rzeczywistość tego sektora, należy uwzględnić możliwość powiązania w całość takich obszarów, jak: edukacja na wszystkich jej poziomach (od podstawowego do wyższego), badania naukowe, szkolenia wynikające z potrzeb zdobywania nowej wiedzy nieobjętej systemem edukacji. Wówczas obszary wiejskie będą atrakcyjnym miejscem życia i pracy. 


\section{Podsumowanie i wnioski}

Powszechnie coraz bardziej docenia się znaczenie jakości czynnika ludzkiego przy kreowaniu postępu w rozwoju gospodarczym. W pracy podjęto próbę ukazania uwarunkowań kształtujących jakość kapitału ludzkiego w województwie podlaskim, z wyszczególnieniem obszarów wiejskich. Szczególny nacisk położono na poziom wykształcenia mającego wpływ na jakość kapitału ludzkiego. Z przeprowadzonych analiz wynikło, że na przełomie ostatniego dziesięciolecia nastąpiły korzystne zmiany w poziomie jakości kapitału ludzkiego na terenach wiejskich. Można wnioskować o konieczności uaktywnienia działań na rzecz poprawy jakości kapitału ludzkiego na terenach wiejskich. Na skutek migracji mieszkańców wsi do ośrodków miejskich została zachwiana równowaga ludnościowa, objawiająca się procesami starzenia się społeczności (duże udziały osób w wieku poprodukcyjnym czy produkcyjnym mobilnym), co może prowadzić do zjawisk depopulacyjnych i marginalizacji wsi. W wyniku powyższych zjawisk społeczno-demograficznych na obszarach wiejskich utrzymują się niekorzystne warunki rozwoju kapitału ludzkiego w stosunku do terenów miejskich. Niskiego poziomu kwalifikacji ludności wiejskiej nie da się podnieść bez zakrojonego na szeroką skalę rozwoju kształcenia dorosłych na wszystkich poziomach, także w modelach nieformalnych, kursowych. Problem ten dotyczy w dużym stopniu prowadzących gospodarstwa rolne, jak też osób prowadzących działalność gospodarczą na obszarach wiejskich. Na podstawie przeprowadzonych rozważań można sformułować następujące wnioski:

1. Kapitał ludzki jest kategorią wielowymiarową, istotną we wzroście i rozwoju gospodarczym kraju i jego regionów.

2. W latach 2002-2011 na obszarach wiejskich województwa podlaskiego przeciętny poziom kapitału ludzkiego rozumianego w wąskim znaczeniu (czyli wykształcenia) znacznie się poprawił.

3. Starzenie się społeczeństwa i bezrobocie to kluczowy problem regionu.

4. W opracowaniu przedstawiono zasoby ludzkie województwa podlaskiego $\mathrm{z}$ wyodrębnieniem obszarów wiejskich. Znając potencjał demograficzny, jego ogólne zasoby i podstawowe cechy łatwiej jest planować jego wykorzystanie. Zarówno władze wojewódzkie, jak i samorząd terytorialny powinny dołożyć wszelkich starań, aby ten kapitał w jak najszerszym zakresie i jak najlepiej zagospodarować. Ze względu na obserwowane, długotrwałe trudności w gospodarce wiejskiej nie można liczyć na szybkie wchłonięcie przez miasta znacznej części wiejskich zasobów ludzkich. Dlatego też należy stawiać na wielofunkcyjny rozwój obszarów wiejskich.

5. Kluczem do rozwoju kapitału ludzkiego na obszarach wiejskich województwa podlaskiego jest jego doskonalenie przez podnoszenie wykształcenia oraz ciągłe zdobywanie wiedzy i umiejętności, które pozwolą na wzrost przedsiębiorczości.

6. Jakość zasobów kapitału ludzkiego danego regionu jest rezultatem długotrwałych przemian demograficznych, dokonujących się pod wpływem wielu czynników.

7. Kapitał ludzki jako efekt edukacji nie pozostaje bez wpływu na jakość życia człowieka, jego miejsce w strukturze społecznej.

8. Jakość kapitału ludzkiego pozostaje w bezpośrednim związku z edukacją. Rozwój obszarów wiejskich, a także sukces ekonomiczny wielu rodzin, wsi i gmin jest też uzależniony od kwalifikacji ludzi i wykształcenia.

9. Proces doskonalenia kwalifikacji osób dorosłych nadal jest selektywny i ma stosunkowo niewielki zasięg. Należy uznać, że kształcenie osób dorosłych, nie tylko na terenach 
wiejskich, ale także w skali całego województwa czy kraju wciąż ma zakres marginalny. Dlatego też konieczne jest podwyższanie kwalifikacji osób w wieku 30 lat i starszych, zwłaszcza w regionach wiejskich.

10. Polityka regionalna województwa podlaskiego powinna tworzyć i wykorzystywać wszelkie możliwe narzędzia powstrzymujące odpływ zasobów pracy i kapitału ludzkiego. Młodych ludzi można zatrzymać, oferując im możliwość dalszego kształcenia, które przyniesie efekty w postaci znalezienia pracy zgodnej z wykształceniem.

11. Polityka regionalna powinna także wykorzystywać otwartość i przedsiębiorczość młodych ludzi, wprowadzając odpowiednio mniej restrykcyjne obciążenia związane z prowadzeniem działalności gospodarczej.

\section{Literatura}

References

Bank Danych Lokalnych GUS (2015, 27 sierpnia). Pozyskano z: www.stat.gov.pl

Bański, J. (2008). Wiejskie obszary sukcesu gospodarczego. Studia Obszarów Wiejskich, 14, 31-39.

Barro, R.J., Sala-i-Martin, X. (2004). Economic growth. Cambridge, Massachusetts: MIT Press.

Barro, R.J., Lee, J.W. (2011; 2015, 10 czerwca). A New Data Set of Educational Attainment in the World. Pozyskano z: http://www.barrolee.com/papers/Barro_Lee_Human_Capital_Update_2011Nov.pdf

Becker, G.S. (1960). An Economic Analysis of Fertility. W: G.B. Roberts (red.), Demographic and Economic Change in Developed Countries. Universities-National Bureau, 209-240.

Becker, G.S. (1993). Human capital, A theoretical and empirical analysis, with special reference to education, Third edition, Chicago - London: Chicago University Press.

Blang, M. (1976). The empirical status of human capital theory: a slightly jaundiced survey. American Economic Association. Journal of Economic Literature, 14(3), 829-830.

Cichy, K. (2005). Kapitał ludzki w modelach i teoriach wzrostu gospodarczego. Zeszyty Studiów Doktoranckich, 23, 37-41.

Czaja, Z. (2011). Problemy zarządzania zasobami ludzkimi w administracji samorządowej. „Optimum”. Studia Ekonomiczne, 1, 128-136.

Denison, E.F. (1962). The Sources of Growth in the US. New York: Committee for Economic Development. Domański, S.R. (1993). Kapitał ludzki i wzrost gospodarczy, Warszawa: PWN.

Fitz-Enz, J. (2001). Rentowność inwestycji w kapitał ludzki. Kraków: Oficyna Ekonomiczna.

Freinkel, J. (2012; 2015, 10 czerwca). The role of hyaluronan in wound healing. Pozyskano z: http://www. ncbi.nlm.nih.gov/pubmed/22891615

Heffner, K., Rosner A. (2005). Czynniki rozwoju obszarów wiejskich - rola małych miast. W: A. Rosner (red.), Uwarunkowania i kierunki przemian społeczno-gospodarczych na obszarach wiejskich, Warszawa: Wyd. IRWiR PAN, 229-330.

http://www.pops.up.podlasie.pl/index.php/strony/9844.html

Janc, K. (2003). Rola nauki i techniki we współczesnym świecie. W: H. Śmigielska, J. Słodczyk (red.), Geograficzne aspekty globalizacji i integracji europejskiej, Opole: PTG UO, 311-317.

Janc, K., Czapiewski, K.Ł. (2014). Polaryzacja zagadnień edukacyjnych na Mazowszu wyzwaniem rozwoju obszarów wiejskich. Studia Komitetu Przestrzennego Zagospodarowania Kraju PAN, 156, 335357.

Kaleta, A. (2009). Obszar wiejski i koncepcje jego rozwoju. Warszawa: Wyd. FAPA.

Kaplan, R.S., Norton, D.P. (2001). Strategiczna karta wyników. Jak przedłożyć strategię na działanie. Warszawa: PWN.

Król, H., M., Ludwiczyński, A. (red.) (2006). Kapitał ludzki organizacji. W: H. Król, M. Ludwiczyński, Zarządzanie zasobami ludzkimi. Tworzenie kapitału ludzkiego organizacji, Warszawa: PWN, 111119. 
Lukas, R. (1988; 2015, 10 czerwca). Interannual fluctuations of the Mindanao Current in feed from sea level. Pozyskano z: http://onlinelibrary.wiley.com/doi/10.1029/JC093iC06p06744/full

Łukasiewicz, G. (2009). Kapitał ludzki w organizacji pomiar i sprawozdawczość. Warszawa: PWN.

Mankiw, N.G., Romero, D. (1992). A Contribution to the Empirics of Economic Growth. Quarterly Journal of Economics, 107, 407-438.

Mincer, J. (1958). Investment in human capital and personal income distribution. Journal of Political Economy, 66(4), 30-36.

Przyszczypkowski, K. (2002). Partnerstwo edukacyjne jako forma kapitału społecznego w gospodarce opartej na wiedzy, Warszawa: PWN.

Roczniki Statystyczne GUS z lat 2003-2014. GUS (2015, 10 czerwca). Pozyskano z: www.stat.gov.pl

Roczniki Demograficzne GUS z lat 2003-2014. GUS (2015, 10 czerwca). Pozyskano z: www.stat.gov.pl

Romer, P. (1990). Endogenous Technological Change. Journal of Political Economy, 96, 71-102.

Schultz, T.W. (1962). Reflections on investment in man. Journal of Political Economy, 70, 1-8.

Smith, A. (1954). Badania nad natura i przyczynami bogactwa narodów, Warszawa: PWN

Strategia rozwoju województwa podlaskiego do roku 2020 (2015, 27 sierpnia). Pozyskano z: http://www. strategia.wrotapodlasia.pl/pl/ps2/var/resources/154/248/4/srwp_2020_1.pdf

Szanse i zagrożenia oraz potencjalne kierunki rozwoju obszarów wiejskich w Polsce w ujęciu regionalnym. Raport podsumowujący. (2012). Agrotec Polska Sp. z o.o. \& Instytut Geografii i Przestrzennego Zagospodarowania PAN, Warszawa.

Zioło, Z. (2010). Rola zasobów intelektualnych, kapitału ludzkiego i społecznego w procesach rozwoju obszarów wiejskich. W: W. Kamińska, K. Heffner (red.), Kapitał ludzki i społeczny w procesie rozwoju obszarów wiejskich, Studia KPZK PAN T. CXXVI, Warszawa.

Celina Grażyna Gabińska, doktorantka, Uniwersytet w Białymstoku, Wydział Ekonomii i Zarządzania. Zainteresowania naukowe autorki koncentrują się wokół rozwoju przedsiębiorczości, kształcenia, rozwoju zasobów ludzkich w przedsiębiorstwach na obszarach wiejskich.

Celina Grażyna Gabińska doctoral student, University in Białystok, Department of Economics and Management. The author's research interests focus on the development of entrepreneurship, education and development of human resources in enterprises.

\section{Adres/Address:}

Uniwersytet w Białymstoku

Wydział Ekonomii i Zarządzania

ul. Warszawska 63

15-062 Białystok, Polska

e-mail: celinagabinska@wp.pl 